\title{
EFEKTIVITAS EKSTRAK DAUN PANDAN WANGI (Pandanus amaryllifolius) SEBAGAI BIOLARVASIDA TERHADAP LARVA Culex Sp.
}

\author{
Irma Novita Andini Putri ${ }^{1}$, Prayudhy Yushananta ${ }^{2 *}$ \\ 1,2 Politeknik Kesehatan Kemenkes Tanjungkarang
}

\section{Artikel Info :}

Received 12 Februari 2022 Accepted 25 Februari 2022 Available online 28 Februari 2022

Editor: Mei Ahyanti

\section{Keyword :}

Biolarvacides, Culex sp, Pandanus amaryllifolius, concentration, contact time

\section{Kata kunci :}

Biolarvasida, Culex sp, Pandanus amaryllifolius, konsentrasi, waktu kontak

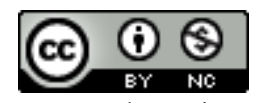

Ruwa Jurai: Jurnal

Kesehatan Lingkungan is licensed under a Creative Commons Attribution-NonCommercial 4.0 International License.

\begin{abstract}
A bstract
The use of chemical pesticides can cause toxic effects for humans, the environment, and nontarget insects. The study aimed to analyze the effect of pandan leaf extract (Pandanus amaryllifolius) on the mortality of Culex sp larvae in instar III developed from residential areas through a two-stage rearing process. The study used a factorial completely randomized design with two replications at four levels of concentration and five levels of contact time. The bioassay test was carried out with 25 larvae in each treatment. The results of the study have proven that concentration affects larval mortality ( $p$-value $=0.000)$, as well as the length of contact time ( $p$ value $=0.003)$, as well as the interaction of concentration and contact time ( $p$-value $=0.00001)$. Concentration showed a stronger association than contact time and concentration and contact time interaction. The $L C_{50}$ value obtained $1.72 \%$. Research has proven that Pandanus amaryllifolius leaf extract can be used as a larvicide against Culex sp. Further research is needed to determine the effect on non-target insects, ready-to-use forms, and comparisons with other bioinsecticides.
\end{abstract}

\begin{abstract}
Penggunaan pestisida kimia dapat menimbulkan efek toksik bagi manusia, lingkungan maupun serangga non target. Penelitian bertujuan untuk menganalisis efektifitas ekstrak daun pandan wangi (Pandanus amaryllifolius) terhadap kematian larva Culex sp instar-III. Eksperimen menggunakan rancangan acak lengkap factorial dengan dua kali ulangan, pada empat level konsentrasi dan lima level waktu kontak. Larva dikembangkan dari daerah pemukiman melalui proses rearing dua tahap. Uji bioassay dilakukan pada setiap perlakuan sebanyak 25 ekor. Hasil penelitian membuktikan bahwa konsentrasi bepengaruh terhadap kematian larva ( $p$ value $=0,000)$, demikian pula lama waktu kontak ( $p$-value $=0,003)$, serta interaksi konsentrasi dan waktu kontak ( $p$-value $=0,00001$ ). Konsentrasi menunjukkan asosiasi yang lebih kuat (88,3\%) dibandingkan waktu kontak $(75,3 \%)$ dan interaksi konsentrasi dan waktu kontak (78,5\%). Nilai $L C_{50}$ diperoleh sebesar 1,72\%. Penelitian telah membuktikan bahwa ekstrak daun Pandanus amaryllifolius dapat digunakan sebagai biolarvasida terhadap larva Culex sp. Perlu penelitian lanjutan untuk mengetahui pengaruh terhadap serangga non target, bentuk sediaan ekstrak siap pakai, serta perbandingan dengan bioinsectisida lainnya.
\end{abstract}

Corresponding author: : Prayudhy Yushananta

J. Soekarno-Hatta No 6, Bandar lampung, Lampung. Indonesia

Email: prayudhyyushananta@gmail.com

\section{PENDAHULUAN}

Nyamuk berperan sebagai vektor berbagai macam parasit pada manusia. Penyakit yang ditularkan melalui vektor menyebabkan morbiditas dan mortalitas yang luas dan merupakan beban ekonomi utama di negara- negara endemik penyakit (Alves, Serrão, \& Melo, 2010; Pavela, 2015). Salah satu penyakit tular vektor yang masih menjadi menjadi perhatian khusus adalah penyakit Filariasis. Penyakit ini disebabkan oleh cacing nematoda yang berasal dari superfamili Filarioidea atau dikenal juga 
dengan Filariae, dan disebarkan oleh arthropoda pengisap darah, umumnya lalat hitam dan nyamuk. Di Indonesia, Genus Culex berperan sebagai vektor utama penularan filariasis (Hidayati \& Suprihatini, 2020). Penyakit filaria tersebar luas di perkotaan maupun pedesaan serta dapat menyerang semua golongan tanpa mengenal usia dan jenis kelamin (Pahlepi, Santoso, Mahdalena, \& Marini, 2020).

Nyamuk Culex merupakan nyamuk pembawa vektor penyakit filaria. Selain itu penyakit yang ditimbulkan antara lain Japanese Enchepalitis (JE), ST. Loius Enchepalitis dan West Nile Virus (WNV) (Ekawasti \& Martindah, 2017). Nyamuk ini mampu berkembang biak pada air tercemar, yang berisi banyak mikroorganisme dan bakteri patogen yang sangat membahayakan. Larva nyamuk sangat aktif memakan mikroorganisme, algae dan kotoran organik (Kusuma, Sumbono, \& Istiqomah, 2020).

Masyarakat di Indonesia cenderung terbiasa menggunakan obat anti nyamuk berbahan kimia yang beredar di pasaran sebagai salah satu cara untuk mengusir dan mencegah berkembangnya nyamuk. Namun, penggunaan bahan kimia dapat menimbulkan efek toksik bagi manusia, lingkungan maupun serangga non target (Pratama \& Yushananta, 2021; Yushananta \& Ahyanti, 2021; Yushananta, Ahyanti, \& Anggraini, 2020). Salah satu cara yang paling aman adalah dengan menggunakan larvasida alami yang berasal dari tanaman yang mempunyai efek racun terhadap serangga (Benelli \& Beier, 2017; Senthil-Nathan, 2020), namun tidak menimbulkan efek samping terhadap manusia dan lingkungan (Pratama \& Yushananta, 2021; Tennyson, Ravindran, \& Arivoli, 2012; Yushananta \& Ahyanti, 2021).

Tanaman yang mengandung larvasida botanik (alami) salah satunya adalah daun pandan wangi (Pandanus amaryllifolius). Daun pandan wangi mengandung senyawa antara lain alkaloid, saponin, tanin dan flavonoid (Indriyani, Rahmayani, \& Wulansari, 2019; Mutiasari \& Kala'Tiku, 2017; Wardani, Adiputra, \& Suardana, 2020). Senyawa alkaloid, saponin, tanin dan flavonoid dapat memberikan efek kematian pada larva melalui pencernaan dan pernafasan (Chaieb, 2017; Hidayati \& Suprihatini, 2020; Indriyani et al., 2019; Kim \& Ahn, 2017; Mutiasari
\& Kala'Tiku, 2017; Pratama \& Yushananta, 2021; Wardani et al., 2020; Yushananta \& Ahyanti, 2021). Penelitian bertujuan untuk menganalisis pengaruh konsentrasi ekstrak daun pandan wangi (Pandanus amaryllifolius) dan lama waktu kontak, terhadap kematian larva Culex sp.

\section{METODE}

\section{Rancangan Penelitian}

Penelitian menggunakan rancangan acak lengkap faktorial dengan dua kali pengulangan. Variabel yang diteliti adalah konsentrasi yang terdiri dari empat level $(2 \%, 4 \%, 6 \%$, dan $8 \%)$ dan waktu kontak yang terdiri dari 5 level (2 jam, 6 jam, 12 jam, 24 jam, dan 48 jam). Penelitian dilakukan di Laboratorium Politeknik Kesehatan Tanjungkarang.

\section{Larva Culex sp. dan rearing}

Proses rearing dilakukan sebanyak dua tahap, untuk mendapatkan larva Culex $s p$ yang murni. Tahap pertama dilakukan dengan cara membiakan telur Culex sp yang diperoleh dari lingkungan dengan menggunakan ovitrap. Telur yang diperoleh selanjutnya ditetaskan dan dilakukan identifikasi larva Culex $s p$ melalui bentuk sifon. Larva yang telah terseleksi selanjutnya dipelihara hingga dewasa dan bertelur. Pemberian pakan larva menggunakan pakan ikan yang dihaluskan, sedangkan pakan dewasa menggunakan darah marmut dan air gula. kemudian menjadi pupa dan nyamuk dewasa. Tahap kedua, menetaskan telur-telur dari nyamuk dewasa hingga menjadi larva instarIII, dan digunakan sebagai subjek penelitian.

Sesuai dengan WHO (2005), uji bioassay menggunakan larva instar-III. Menurut Hidayati \& Suprihatini (2020), larva instar-III memiliki ketahanan hidup yang kuat dan relatif stabil dari pengaruh faktor eksternal. Pada fase instar-I dan instar-II, laju ketahanan hidup fase akuatik dari Culex mengalami masa rentan (Ramadhani, Yuliani, Hadi, Soviana, \& Irawati, 2019).

Pada setiap blok sampel menggunakan 25 ekor larva, dan masing-masing blok sampel dilengkapi dengan kontrol yang juga berjumlah 25 ekor. Jumlah larva Culex sp yang digunakan untuk penelitian sebanyak 2.000 ekor. 


\section{Ekstrak daun pandan wangi}

Ekstraksi daun pandan wangi (Pandanus amaryllifolius) dilakukan dengan metode maserasi. Daun pandan wangi yang diperoleh dari pasar tradisional, dicuci menggunakan air sumur dan dibilas dengan air destilasi, selanjutnya dipotong halus. Potongan halus dikeringkan dengan cara diangin-anginkan selama tujuh hari, tidak terkena sinar matahari langsung. Potongan daun yang sudah kering dihaluskan menggunakan blender dan ditimbang sebanyak 800 gram bubuk sebagai bahan ekstrak. Proses ekstraksi dilakukan dengan cara merendam bubuk daun pandan wangi menggunakan $1.000 \mathrm{ml}$ etanol $70 \%$ di dalam labu ukur tertutup selama $3 \times 24 j a m$. Larutan hasil rendaman selanjutnya disaring menggunakan kertas saring dan dilakukan penguapan menggunakan waterbath hingga mengental. Cairan kental hasil ekstraksi selanjutnya digunakan sebagai larutan induk (100\%) ekstrak pandan wangi (Pandanus amaryllifolius).

Pengenceran ekstrak daun pandan wangi dengan menggunakan air sumur (WHO, 2005). Metode pengenceran untuk mendapatkan 100 $\mathrm{ml}$ konsentrasi $2 \%, 4 \%, 6 \%$ dan $8 \%$, menggunakan formula :

$$
\begin{aligned}
& V_{1} \cdot M_{1}=V_{2} \cdot M_{2}(1) \\
& \text { Keterangan: } \\
& V_{1}=\text { Volume awal } \\
& M_{1}=\text { Konsentrasi larutan induk } \\
& V_{2}=\text { Volume setelah pengenceran } \\
& M_{2}=\text { Konsentrasi setelah pengenceran }
\end{aligned}
$$

\section{Percobaan}

Sebanyak 25 ekor larva Culex sp instar-III dimasukkan ke dalam wadah uji dan dipaparkan ekstrak pandan wangi (Pandanus amaryllifolius) dengan konsentrasi 2\%, 4\%,6\% dan $8 \%$. Pada blok kontrol hanya menggunakan $100 \mathrm{ml}$ air sumur. Perlakuan dilakukan dengan dua kali ulangan dan randomisasi blok pada setiap ulangan.

Selama perlakuan, juga dilakukan pengukuran suhu dan $\mathrm{pH}$ pada masing-masing wadah uji. Pengamatan kematian larva dilakukan pada waktu 2 jam, 6 jam, 12 jam, 24 jam, dan 48 jam.

\section{Analisis Data}

Mengikuti (WHO, 2005), kematian larva ditentukan berdasarkan visual serta kondisi larva, yaitu tenggelam ke dasar wadah, tidak bergerak, dan tidak merespons rangsangan berupa sentuhan menggunakan lidi pada bagian sifon. Pencatatan kematian dilakukan pada setiap blok sampel. Selanjutnya dianalisis untuk mengetahui pengaruh variabel penelitian.

Analisis data untuk mengetahui pengaruh tunggal dan gabungan variabel penelitian (konsentrasi dan waktu kontak) menggunakan analisis Anova Two-way. Uji Tukey menentukan perbedaan yang signifikan antara level perlkuan. Semua dianalisis menggunakan perangkat statistik SAS 9.4.

\section{HASIL}

Tabel 1 menunjukkan distribusi kematian larva berdasarkan konsentrasi ekstrak pandan wangi (Pandanus amaryllifolius), dan waktu kontak. Berdasarkan konsentrasi ekstrak, rerata kematian larva Culex $s p$ terendah pada konsentrasi $2 \%$, (13,4 larva), dan tertinggi pada konsentrasi $6 \%$ dan $8 \%$, sebanyak 25,0 larva (Gambar 1a). Hasil ini menujukkan bahwa semakin tinggi konsentrasi ekstrak Pandanus amaryllifolius, maka semakin tinggi pula tingkat kematian larva Culex sp.

Berdasarkan waktu kontak (Gambar 1b), kematian terendah setelah kontak selama 2 jam (15,6 larva) dan tertinggi selama 48 jam (25,0 larva). Menujukkan bahwa semakin lama waktu paparan, maka semakin tinggi pula tingkat kematian larva.

Tabel 1. Rerata kematian larva Culex sp berdasarkan konsentrasi dan waktu kontak

\begin{tabular}{lllllll}
\hline Konsentrasi/Waktu & 2 jam & 6 jam & 12 jam & 24 jam & 48 jam & Rerata \\
\hline $2 \%$ & 2,5 & 4 & 16,5 & 19 & 25 & 13,4 \\
$4 \%$ & 10 & 18 & 25 & 25 & 25 & 20,6 \\
$6 \%$ & 25 & 25 & 25 & 25 & 25 & 25,0 \\
$8 \%$ & 25 & 25 & 25 & 25 & 25 & 25,0 \\
\hline Rerata & 15,6 & 18,0 & 22,9 & 23,5 & 25,0 & 21,0 \\
\hline
\end{tabular}




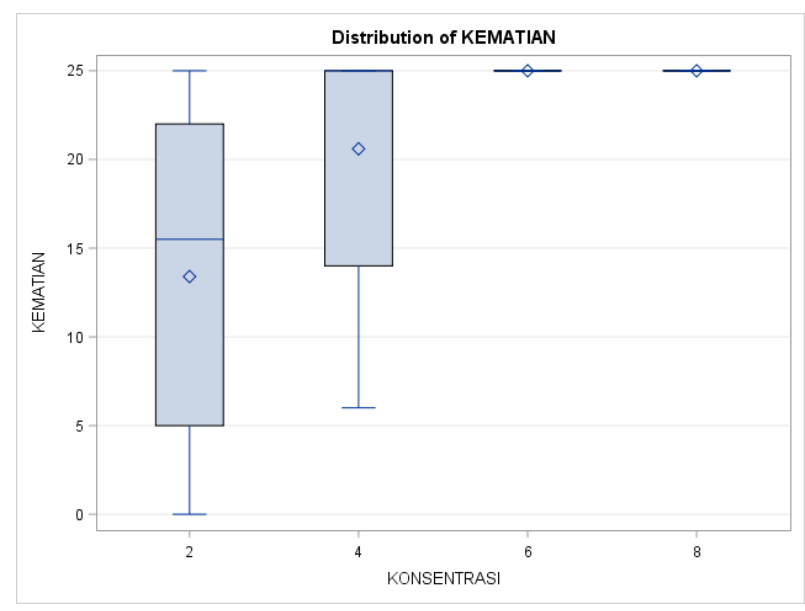

(a)

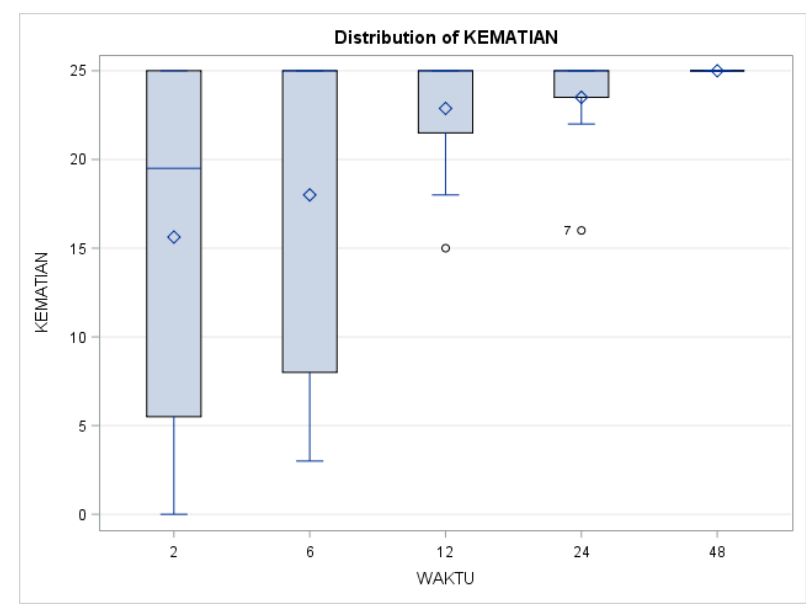

(b)

Gambar 1. Rerata kematian larva Culex sp berdasarkan konsentrasi ekstrak (a), dan waktu kontak (b)

1. Kematian larva berdasarkan konsentrasi

Penelitian menggunakan empat level konsentrasi ekstrak pandan wangi (Pandanus amaryllifolius), yaitu 2\%, 4\%, 6\%, dan $8 \%$. Hasil pengujian (Tabel 2) menunjukkan perbedaan rerata kematian larva Culex sp berdasarkan level konsentrasi ( $p$-value $<0,0001$ ).

Uji Tukey HSD dilakukan untuk mengetahui perbedaan kematian larva berdasarkan masing- masing konsentrasi ekstrak (Tabel 3). Hasil analisis menunjukkan perbedaan kematian larva antara konsentrasi $2 \%$ dengan $6 \%$ dan $8 \%$ $(p$-value $=0,001)$. Sedangkan kematian larva pada konsentrasi $2 \%$ dan $4 \%$, tidak menunjukkan perbedaan yang signifikan. Demikian pula pada konsentrasi $6 \%$ dan $8 \%$, juga tidak menunjukkan perbedaan yang signifikan.

Tabel 2. Pengaruh kematian larva Culex sp berdasarkan konsentrasi

\begin{tabular}{lllllll}
\hline Source & DF & SS & MS & F-value & P-value & $\begin{array}{l}\text { Partial Eta } \\
\text { Squared }\end{array}$ \\
\hline Konsentrasi & 3 & 899,20 & 299,73 & 35,90 & $<0,0001$ & 0,843 \\
Waktu kontak & 4 & 509,25 & 127,31 & 15,25 & $<0,0001$ & 0,753 \\
Konsentrasi*Waktu & 12 & 610,55 & 50,88 & 6,09 & 0.0002 & 0,785 \\
R-Square & 0,923 & & & & & \\
\hline
\end{tabular}

Tabel 3. Hasil Uji Tukey HSD (konsentrasi)

\begin{tabular}{lllll}
\hline Konsentrasi & $2 \%$ & $4 \%$ & $6 \%$ & $8 \%$ \\
\hline $2 \%$ & - & $>0,05$ & 0,001 & 0,001 \\
$4 \%$ & $>0,05$ & - & $>0,05$ & $>0,05$ \\
$6 \%$ & 0,001 & $>0,05$ & - & $>0,05$ \\
$8 \%$ & 0,001 & $>0,05$ & $>0,05$ & - \\
\hline
\end{tabular}

2. Kematian larva berdasarkan waktu kontak Lima level waktu kontak dilakukan selama penelitian, yaitu 2 jam, 6 jam, 12 jam, 24 jam, dan 48 jam. Hasil pengujian (Tabel 2) menunjukkan perbedaan rerata kematian larva Culex $s p$ berdasarkan level waktu kontak ( $p$-value $<0,0001$ ).
Uji Tukey HSD dilakukan untuk mengetahui perbedaan kematian larva berdasarkan masingmasing waktu kontak (Tabel 4). Hasil analisis menunjukkan perbedaan kematian larva antara waktu kontak 2 jam dengan 12 jam ( $p$-value $=0,043)$, dan 2 jam dengan 48 jam $(p$-value $=0,038)$. Sedangkan sisanya tidak 
menunjukkan perbedaan yang signifikan ( $p$-value $>0,05)$.

\section{Kematian larva berdasarkan konsentrasi dan} waktu kontak

Analisis dilakukan untuk mengetahui peredaan kematian larva berdasarkan interaksi konsentrasi dan waktu kontak. Secara signifikan hasil analisis (Tabel 2) menunjukkan perbedaan rerata kematian larva Culex $s p$ berdasarkan konsentrasi dan waktu kontak ( $p$-value $=0,0002$ ).

Gambar 2 menunjukkan bahwa rerata kematian terendah pada konsentrasi $2 \%$ dengan waktu kontak selama 2 jam (2,5 larva). Total kematian larva pada konsentrasi ekstrak 2\%, diperoleh setelah waktu kontak 48 jam.

Tabel 4. Hasil Uji Tukey HSD (waktu kontak)

\begin{tabular}{llllll}
\hline Waktu kontak & 2 jam & 6 jam & 12 jam & 24 jam & 48 jam \\
\hline 2 jam & - & $>0,05$ & 0,043 & $>0,05$ & 0,038 \\
6 jam & $>0,05$ & - & $>0,05$ & $>0,05$ & $>0,05$ \\
12 jam & 0,043 & $>0,05$ & - & $>0,05$ & $>0,05$ \\
24 jam & $>0,05$ & $>0,05$ & $>0,05$ & - & $>0,05$ \\
48 jam & 0,038 & $>0,05$ & $>0,05$ & $>0,05$ & - \\
\hline
\end{tabular}

Penggunaan konsentrasi ekstrak 4\% menunjukkan hasil yang bervariasi berdasarkan waktu kontak. Rerata kematian larva setelah kontak selama 2 jam sebanyak 10,0 larva, dan selama 6 jam sebanyak 18,0 larva. Kematian total larva Culex sp setelah terpapar ekstrak selama 12 jam, 24 jam, dan 48 jam.

Pada konsentrasi $6 \%$ dan $8 \%$, percobaan memberikan efek kematian terhadap seluruh larva, pada seluruh level waktu kontak. Hasil ini menunjukkan bahwa konsentrasi ekstrak memiliki peran yang lebih dominan terhadap kematian larva Culex sp. Nilai Partial Eta Squared (Tabel 1) juga menunjukkan bahwa konsentrasi memiliki hubungan yang lebih erat, dibandingkan variabel waktu kontak.

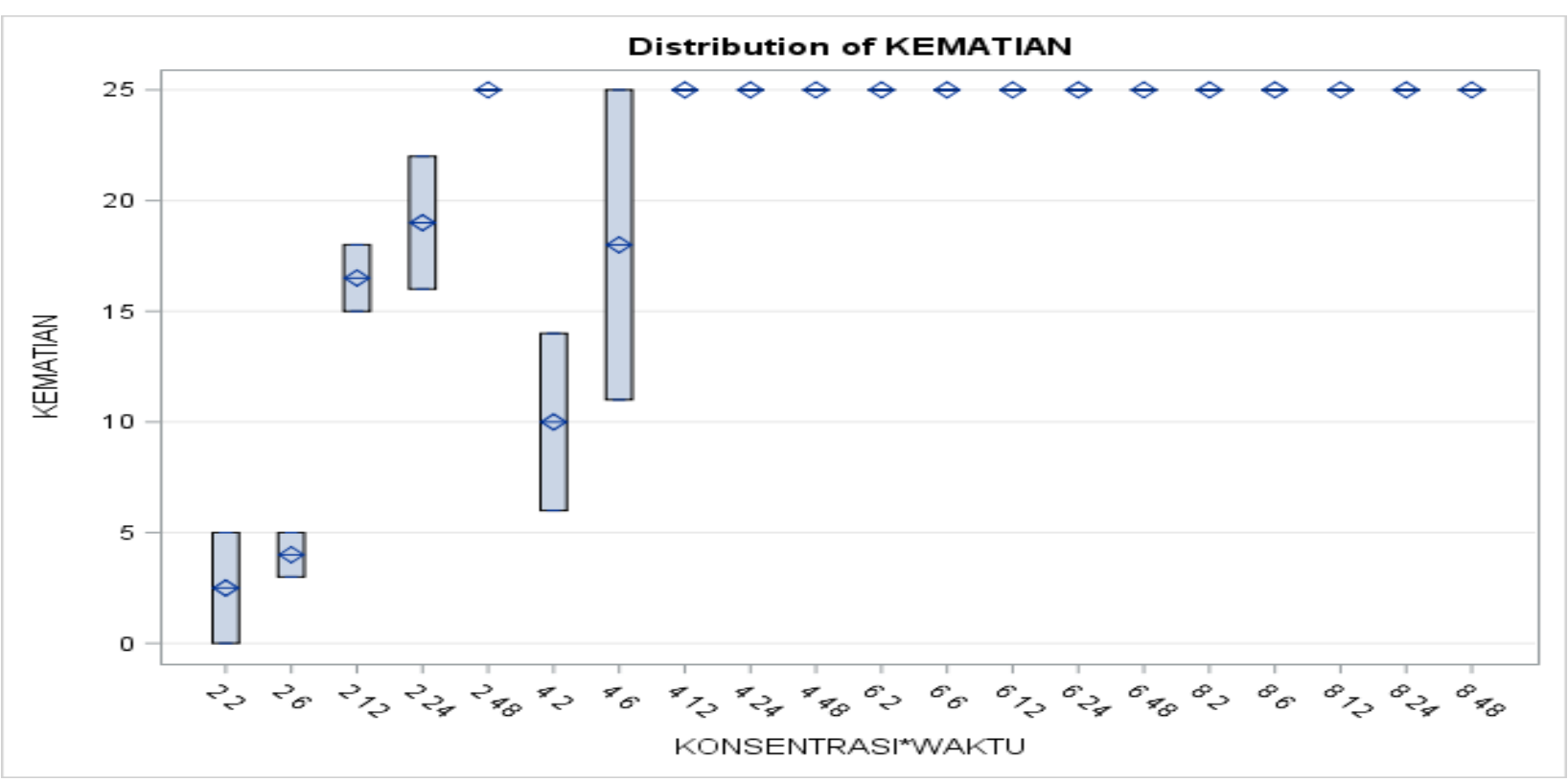

Gambar 2. Rerata kematian larva Culex sp berdasarkan konsentrasi ekstrak dan waktu kontak

4. Lethal Concentration ( $\left.L C_{50}\right)$

Hasil uji BSLT (Brine Shrimp Lethality Test) untuk menentukan efektivitas $\mathrm{LC}_{50}$ (konsentrasi yang menyebabkan kematian sebesar 50\%) didapatkan persamaan garis linear yaitu $y=4,346 x+(-13,20)$. Dari hasil perhitungan 
tersebut, maka konsentrasi yang efektif untuk mematikan larva 50\% Culex sp adalah 1,72\%.

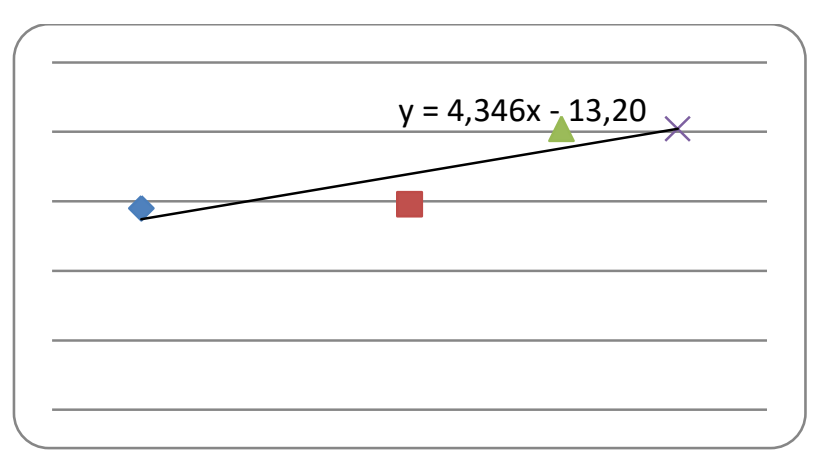

Gambar 3. Persamaan linear ekstrak Pandanus amaryllifolius dan kematian larva Culex $s p$

\section{PEMBAHASAN}

Hasil penelitian mendapatkan perbedaan rata-rata kematian larva Culex sp berdasarkan konsentrasi ekstrak daun pandan wangi (Pandanus amaryllifolius), menunjukkan pengaruh konsentrasi terhadap kematian larva $(P<0,05)$. Konsentrasi dan kematian larva menunjukkan hubungan yang sangat erat (84,3\%). Rata-rata kematian terendah pada konsentrasi $2 \%$, dan tertinggi pada $6 \%$ dan $8 \%$. Hasil ini sekaligus menunjukkan bahwa semakin tinggi konsentrasi ekstrak, maka semakin tinggi kematian larva. Hasil penelitian juga mendapatkan bahwa kematian total larva diperoleh pada konsentrasi $6 \%$ dan $8 \%$.

Konsentrasi sejalan dengan jumlah kandungan bahan aktif dalam ekstrak yang berperan sebagai biopestisida (Pratama \& Yushananta, 2021; Yushananta \& Ahyanti, 2021). Semakin tinggi konsentrasi, maka semakin tinggi pula kandungan bahan aktif. Hasil penelitian ini sesuai dengan beberapa penelitian sebelumnya yang menyebutkan bahwa semakin tinggi konsentrasi ekstrak daun pandan wangi (Pandanus amaryllifolius), maka kematian larva juga akan meningkat (Kasma, Ridjal, \& M, 2019; Triwahyuni, Husna, Febriani, \& Karim, 2021). Hubungan konsentrasi dengan jumlah kematian larva juga diperoleh pada penelitian yang menggunakan ekstrak buah Pare (Momordica charantia) (Syam \& Pawenrusi, 2017), ekstrak daun pepaya (C. papaya) (Ningsi, Yuniar, \& Fachlevy, 2016), ekstrak daun Maja (Aegle marmelos) (Pratama \& Yushananta, 2021; Puspa Sari \& Priastini Susilowati, 2019), dan ekstrak daun sirih (Piper betle) (Yushananta \& Ahyanti, 2021).

Paparan senyawa flavonoid, dan saponin yang terdapat pada ekstrak biopestisida mengakibatkan kerusakan toraks dan abdomen larva. Saponin akan menghambat kemampuan makan larva sehingga mengakibatkan kematian (Chaieb, 2017; Hidayati \& Suprihatini, 2020; Pratama \& Yushananta, 2021; Yushananta \& Ahyanti, 2021). Selain itu, saponin dan alkaloid akan mempengaruhi kerja enzim koliesterase larva. Flavonoid bersifat respiratory poison dan polifenol bersifat stomach poison, sehingga mengakibatkan kematian pada larva.

Waktu kontak menunjukkan pengaruh yang signifikan terhadap kematian larva Culex $s p$ ( $p$-value $<0,05)$, dengan keeratan hubungan $75,3 \%$. Rata-rata kematian terendah pada waktu kontak 2 jam, dan tertinggi selama 48 jam. Hasil Uji Tukey HSD memberikan gambaran bahwa perbedaan kematian larva pada waktu kontak 2 jam dengan 12 jam dan 48 jam. Hasil ini menunjukkan bahwa semakin lama waktu kontak, maka semakin tinggi kematian larva Culex sp.

Kematian yang rendah pada waktu kontak 2 jam (pada konsentrasi $2 \%$ dan 4\%), karena larva masih mampu bertahan terhadap paparan ekstrak daun pandan wangi (Pandanus amaryllifolius). Kematian meningkat setelah paparan 12 jam. Pada konsentrasi $6 \%$ dan $8 \%$, waktu kontak tidak menunjukkan perbedaan yang bermakna terhadap kematian larva Culex $s p$. Hasil percobaan memberikan kematian terhadap seluruh larva, mulai dari waktu kontak terendah.

Hasil penelitian ini telah membuktikan bahwa semakin lama waktu kontak terhadap ekstrak daun pandan wangi (Pandanus amaryllifolius), maka akan meningkatkan kematian larva Culex $s p$. Hasil penelitian ini sesuai dengan beberapa penelitian biopestisida sebelumnya yang menyebutkan bahwa waktu kontak berkaitan dengan tingkat kematian (Pratama \& Yushananta, 2021; Yushananta \& Ahyanti, 2021). Pada waktu paparan yang rendah, senyawa racun belum memberikan efek kerusakan pada toraks dan abdomen, sehingga belum berakibat pada kematian (Chaieb, 2017; Hidayati \& Suprihatini, 2020; Yushananta \& Ahyanti, 2021). 
Menurut Ningsi et al. (2016), semakin lama waktu kontak maka daya bunuh ekstrak yang akan merusak berbagai reaksi di dalam tubuh larva dapat mengganggu pernafasan, pertumbuhan dan perkembangan dari larva sehingga menyebabkan kematian.

Interaksi konsentrasi ekstrak dan waktu kontak menunjukkan pengaruh yang signifikan ( $p$-value $=0,0002)$, dengan keeratan hubungan $78,5 \%$. Gambar 2 menunjukkan bahwa kematian total larva Culex sp diperoleh pada konsenntrasi $6 \%$ dan $8 \%$, pada semua waktu kontak. Sedangkan pada pemakaian konsentrasi rendah (2\% dan 4\%), kematian toatal setelah paparan selama 48 jam dan 12 jam. Hasil penelitian ini membuktikan bahwa ekstrak daun pandan wangi (Pandanus amaryllifolius) efektif digunakan pada konsentrasi $2 \%$ dengan waktu kontak 48 jam. Menurut WHO (2005), lama waktu kontak untuk penilaian efektifitas larvasida hingga 48 jam.

Hasil perhitungan $\mathrm{LC}_{50}$ juga telah memberikan informasi bahwa konsentrasi efektif terhadap kematian 50\% larva Culex sp adalah konsentrasi 1,72\%. Hasil penelitian ini mendapatkan nilai $\mathrm{LC}_{50}$ lebih rendah dibandingkan penggunaannya terhadap larva Aedest aegypti, yaitu sebesar 2,213\% (Mutiasari \& Kala'Tiku, 2017), dan 9,445\% (Kasma et al., 2019). Pada larva Anopheles, nilai $L_{50}$ ekstrak Pandanus amaryllifolius sebesar 14,874 (Kasma et al., 2019).

Beberapa penelitian lainnya juga telah melaporkan $\mathrm{LC}_{50}$ pada penggunaan beberapa bahan alami. Penggunaan ekstrak daun sirih hijau (Piper betle) pada larva Aedest aegypti membutuhkan konsentrasi 5,556\% (Adibah \& Dharmana, 2017), ekstrak biji pangi (Pangium edule Reinw) sebesar 0,053\% (Sampe \& Watuguly, 2016), daun maja (Aegle marmelos) sebesar 4,12\% (Puspa Sari \& Priastini Susilowati, 2019), ekstrak daun pepaya (Carica Papaya L.) terhadap larva nyamuk Anopheles aconitus donits sebesar 0,0424\% (Ningsi et al., 2016), dan ekstrak biji mahoni (Swietenia mahagoni) terhadap larva Culex sebesar 10\% (Hidayati \& Suprihatini, 2020). Berdasarkan hasil-hasil penelitian tersebut, maka penggunaan ekstrak daun pandan wangi (Pandanus amaryllifolius) sebagai larvasida terhadap larva nyamuk Culex sp. masih layak digunakan, mengingat kemudahan dan nilai ekonomis dari bahan baku.

\section{SIMPULAN}

Penelitian telah membuktikan bahwa ekstrak daun pandan wangi (Pandanus amaryllifolius) dapat digunakan sebagai larvasida terhadap jentik nyamuk Culex sp. Rerata kematian tersendah larva Culex $s p$ pada konsentrasi $2 \%$, dan tertinggi pada $6 \%$ dan $8 \%$. Berdasarkan waktu kontak, kematian terendah setelah paparan selama 2 jam, dan tertinggi setelah 48 jam. Hasil analisis statistik telah menunjukkan pengaruh yang signifikan ( $p$-value $<0,05)$, berdasarkan konsentrasi, waktu paparan, sarta interaksi konsentrasi dan waktu paparan. Berdasarkan analisis probit, nilai LC $_{50}$ sebesar $1,72 \%$.

\section{DAFTAR PUSTAKA}

Adibah, A., \& Dharmana, E. (2017). Larvicidal Effectiveness Test of Boiled Betle Leaf (Piper betle L.) Against Aedes aegypti Larvae: Studies in Value of Lc50, Lt50, and The Rate of Larvae Mortality. Diponegoro Medical Journal, 6(2), 244-252.

Alves, S. N., Serrão, J. E., \& Melo, A. L. (2010). Alterations in the fat body and midgut of Culex quinquefasciatus larvae following exposure to different insecticides. Micron, 41(6), 592-597. https://doi.org/10.1016/j.micron.2010.04.004

Benelli, G., \& Beier, J. C. (2017). Current vector control challenges in the fight against malaria. Acta Tropica, 174, 91-96. https://doi.org/10.1016/j.actatropica.2017.06.0 28

Chaieb, I. (2017). Saponins as Insecticides: A Review Saponins as Insecticides: a Review, Tunisian. Journal of Plant. Protection, 5(1), 39 50.

Ekawasti, F., \& Martindah, E. (2017). Vector Control of Zoonotic Arbovirus Disease in Indonesia. Indonesian Bulletin of Animal and Veterinary Sciences, 26(4), 151. https://doi.org/10.14334/wartazoa.v26i4.1402

Hidayati, L., \& Suprihatini, S. (2020). Pengaruh Pemberian Ekstrak Biji Mahoni (Swietenia mahagoni) Terhadap Kematian Larva Culex sp. ASPIRATOR - Journal of Vector-Borne Disease Studies, 12(1), 45-52. https://doi.org/10.22435/asp.v12i1.2171 
Indriyani, I., Rahmayani, I., \& Wulansari, D. (2019). Upaya Pengendalian Hama Gudang Sitophilus oryzaeL.Dengan Penggunaan Pestisida Nabati. Jurnal Ilmiah Ilmu Terapan Universitas JambilIITUJ|, 3(2), 126-137. https://doi.org/10.22437/jiituj.v3i2.8196

Kasma, A. Y., Ridjal, A. T. M., \& M, R. (2019). Efektivitas Ekstrak Daun Pandan Wangi (Pandanus amaryllifolius) Terhadap Mortalitas Larva Aedes sp dan Anopheles. Jurnal Vektor Penyakit, 13(2), 107-114. https://doi.org/10.22435/vektorp.v13i2.465

Kim, S. II, \& Ahn, Y. J. (2017). Larvicidal activity of lignans and alkaloid identified in Zanthoxylum piperitum bark toward insecticide-susceptible and wild Culex pipiens pallens and Aedes aegypti. Parasites and Vectors, 10(1), 1-10. https://doi.org/10.1186/s13071-017-2154-0

Kusuma, R. D., Sumbono, A., \& Istiqomah. (2020). Identifikasi Toksisitas Larutan Smilax Sp Terhadap Perilaku Larva Culicidae. Biolearning Journal, 7(2), 40-48.

https://doi.org/https://doi.org/10.36232/jurnal biolearning.v7i2.557

Mutiasari, D., \& Kala'Tiku, L. L. B. T. (2017). Uji Efektifitas Ekstrak Daun Pandan (Pandanus amaryllifolius Roxb .) Sebagai Larvasida Alami Terhadap Larva Aedes aegypti. Kesehatan Tadulako, 3(2), 31-39.

https://doi.org/https://doi.org/10.22487/htj.v3i 2.48

Ningsi, E., Yuniar, N., \& Fachlevy, A. (2016). Efektivitas Uji Daya Bunuh Ekstrak Daun Pepaya (Carica Papaya L.) Terhadap Larva Nyamuk Anopheles Aconitus Donits Dalam Upaya Pencegahan Penyakit Malaria Di Daerah Persawahan Desa Lalonggombu Kecamatan Andoolo Kabupaten Konawe Selatan. Jurnal Ilmiah Mahasiswa Kesehatan Masyarakat Unsyiah, 1(3), 183424.

Pahlepi, R. I., Santoso, S., Mahdalena, V., \& Marini, M. (2020). Culex vishnui Sebagai Vektor Filariasis Potensial di Kabupaten Kuantan Singingi, Provinsi Riau. ASPIRATOR - Journal of Vector-Borne Disease Studies, 12(1), 1-10. https://doi.org/10.22435/asp.v12i1.3040

Pavela, R. (2015). Acute toxicity and synergistic and antagonistic effects of the aromatic compounds of some essential oils against Culex quinquefasciatus Say larvae. Parasitology Research, 174(10), 3835-3853. https://doi.org/10.1007/s00436-015-4614-9

Pratama, S. D., \& Yushananta, P. (2021). Efektivitas
Ekstrak Kulit Batang Maja (Aegle marmelos L) Terhadap Kematian Larva Nyamuk Anopheles sp. Ruwa Jurai: Jurnal Kesehatan Lingkungan, 15(2), 67. https://doi.org/10.26630/rj.v15i2.2813

Puspa Sari, M., \& Priastini Susilowati, R. (2019). Efektivitas Ekstrak Daun Maja (Aegle marmelos (L) Corr) sebagai Larvasida Aedes aegypti. YARSI Medical Journal, 27(1), 001. https://doi.org/10.33476/jky.v27i1.797

Ramadhani, T., Yuliani, V., Hadi, U. K., Soviana, S., \& Irawati, Z. (2019). Tabel Hidup Nyamuk Vektor Filariasis Limfatik Culex quinquefasciatus (Diptera: Culicidae) di Laboratorium. JURNAL KESEHATAN LINGKUNGAN INDONESIA, 18(2), 73. https://doi.org/10.14710/jkli.18.2.73-80

Sampe, V., \& Watuguly, T. (2016). Efektivitas Ekstrak Biji Pangi (Pangium edule Reinw) Terhadap Mortalitas Larva Nyamuk Anopheles. BIOPENDIX: Jurnal Biologi, Pendidikan Dan Terapan, 2(2), 152-159.

https://doi.org/10.30598/biopendixvol2issue2 page 152-159

Senthil-Nathan, S. (2020). A Review of Resistance Mechanisms of Synthetic Insecticides and Botanicals, Phytochemicals, and Essential Oils as Alternative Larvicidal Agents Against Mosquitoes. Frontiers in Physiology, 10. https://doi.org/10.3389/fphys.2019.01591

Syam, I., \& Pawenrusi, E. P. (2017). Efektifitas Ekstrak Buah Pare(Momordica charantia) Dalam Mematikan Jentik Aedes aegypti. Jurnal Kesehatan Masyarakat Andalas, 10(1), 19. https://doi.org/10.24893/jkma.v10i1.158

Tennyson, S., Ravindran, K. J., \& Arivoli, S. (2012). Screening of twenty five plant extracts for larvicidal activity against Culex quinquefasciatus Say (Diptera: Culicidae). Asian Pacific Journal of Tropical Biomedicine, 2(2), S1130-S1134. https://doi.org/10.1016/S2221-1691(12)603724

Triwahyuni, T., Husna, I., Febriani, D., \& Karim, L. I. (2021). Efektivitas Ekstrak Daun Pandan Wangi (Pandanus Amaryllifolius) Terhadap Daya Tahan Larva Anopheles Sp. Manuju: Malahayati Nursing Journal, 3(3), 413-425.

Wardani, N. P. I. P. P., Adiputra, I. G. K., \& Suardana, A. A. K. (2020). Efektivitas Repelensi Serbuk Daun Pandan Wangi (Pandanus amaryllifolius Roxb) Terhadap Kutu Beras (Sitophilus oryzae L) Pada Beras Merah (Oryza nivara). Jurnal Widya Biologi, 11(01), 30-40. 
https://doi.org/10.32795/widyabiologi.v11i01.5 68

WHO. (2005). Guidelines for laboratory and field testing of mosquito larvicides. In World Health Organization.

Yushananta, P., \& Ahyanti, M. (2021). The effectiveness of betle leaf (Piper betle L.) extract as a bio-pesticide for controlled of houseflies (musca domestica L.). Open Access
Macedonian Journal of Medical Sciences, 9, 895-900.

https://doi.org/10.3889/oamjms.2021.6886 Yushananta, P., Ahyanti, M., \& Anggraini, Y. (2020). Risk of pesticides on anaemia events in horticulture farmers. International Journal of Innovation, Creativity and Change, 13(2), 3040. 